Research Article

\title{
Bond Financing, Research and Development Input, and Total Factor Productivity
}

\author{
Xing $\mathrm{He}^{1}$ and Mancang Wang $\mathbb{D}^{2}$ \\ ${ }^{1}$ School of Management, Yulin University, Yulin 719000, China \\ ${ }^{2}$ School of Finance, Xi'an Eurasia University, Xi'an 710127, China \\ Correspondence should be addressed to Mancang Wang; 20131925@nwu.edu.cn
}

Received 24 August 2021; Revised 28 September 2021; Accepted 29 September 2021; Published 12 October 2021

Academic Editor: Ahmed Farouk

Copyright (c) 2021 Xing He and Mancang Wang. This is an open access article distributed under the Creative Commons Attribution License, which permits unrestricted use, distribution, and reproduction in any medium, provided the original work is properly cited.

\begin{abstract}
From the angle of research and development $(R \& D)$ input, this paper analyzes how bond financing affects corporate total factor productivity (TFP). Based on the 2007-2019 data on listed enterprises, the influence and action mechanism of bond financing on corporate TFP were empirically examined. The results show that bond financing significantly boosts corporate TFP. The mechanism analysis reveals that bond financing promotes TFP by stimulating corporate R\&D input. The research sheds new light on the relationship between finance and TFP from the perspective of bond financing and provides a reference for policymakers to boost corporate TFP by promoting bond financing.
\end{abstract}

\section{Introduction}

Chinese President clearly suggested that the Chinese economy has moved from the high-speed growth stage to the high-quality development stage. Hence, China now needs to complete three critical tasks: transform development mode, optimize economic structure, and change growth drivers. Economic growth requires the input of various elements, e.g., capital, labor, and land, which cannot be significantly improved in the short term. Therefore, an important source of economic growth is to improve total factor productivity (TFP) through technical innovation and management optimization. As the key to corporate competitiveness, innovation refers to the re-combination of production factors and conditions. However, many enterprises are reluctant to invest in research and development $(\mathrm{R} \& \mathrm{D})$, owing to the uncertainty and high cost of innovation activity.

In the meantime, bond financing becomes an important debt financing tool of listed enterprise. The public data show that Chinese enterprises issued a total of 385.109 billion yuan of bonds in 2020, an increase of $13.91 \%$ year-on-year. In the same year, the publicly issued corporate bonds on China's exchange market totaled 1.52 trillion yuan, an increase of
40.22\% year-on-year (Wind database); 1.84 trillion yuan of enterprise bonds was privately raised on that market, an increase of $26.45 \%$ year-on-year. The bond financing of listed companies has the advantages of low capital cost and wide financing range and constantly drives the high-quality development of the economy and society.

To facilitate the transformation of Chinese economy, it is very important to study whether corporate bond financing could promote R\&D input, and thus stimulate TFP.

Since its proposal by Romer [1], the theory of endogenous growth has been adopted by domestic and foreign scholars as the research framework for the influence of financial development on TFP. Despite reaching fruitful results, the scholars still differ in conclusions. Some scholars held that financial development promotes TFP growth by driving technical progress and improving resource allocation efficiency [2-4]. Some scholars argued that financial development does not affect or even suppresses corporate TFP, due to the mismatch of credit resources in the financial market [5-7].

Although much results are available on the macrolevel, there are very few reports on how financial development affects corporate TFP on the microlevel. Gatti and Love [8] 
investigated the survey data on Bulgaria and discovered that enterprises lacking credit channels have relatively low productivity. Krishnan et al. [9] demonstrated that bank deregulation could elevate the TFP of American manufacturers. Caggese [10] also found that the productivity increment of Italian enterprises is negatively correlated with the financing constraint in the industry. Chinese scholars proved that the financial friction caused by information asymmetry leads to financing constraints on enterprises, which in turn brings productivity loss to enterprises [11]. It is easy to infer from the existing studies that an important means to enhance corporate TFP is to provide financial support to enterprises, especially to corporate R\&D.

Under the bank-dominated financial system, enterprises have difficulty in acquiring effective financial support to innovation activities. Compared to bank loans, equity financing provides an easy source of innovation input $[12,13]$. Nevertheless, bank loans take up more than $50 \%$ of financing among Chinese enterprises, while the proportion of external sources such as equity financing is smaller than $10 \%$ (source: Wind database). Similar to stocks, corporate bonds are mainly issued in public market and support timely information generation, dissemination, and feedbacks. Unlike short-term financing such as bank loans, bond financing usually offers a maturity date far out on the investment horizon. Therefore, the financing period can better match with long investment horizon.

Since bank loans cannot effectively support corporate innovation input and equity financing cannot be realized easily, it is important to answer the following question: could bond financing promote enterprises to step up R\&D input, and thus enhance corporate TFP? However, few scholars have examined the influence of corporate bond financing on TFP. Therefore, this paper studies whether bond financing promotes TFP from the angle of corporate R\&D input.

This paper has two marginal contributions. First, we confirmed that bond financing could influence corporate TFP, which enriches the relationship between finance and corporate TFP. Second, our results shed new light on the action of bond financing on enterprises and provide new evidence to the promotion of capital market development.

The remainder of this paper is organized as follows. Section 2 carries out a theoretical analysis and presents hypotheses. Section 3 designs an empirical analysis. Section 4 presents the empirical results. Section 5 gives the conclusions and policy suggestions.

\section{Theoretical Analysis and Hypotheses}

2.1. Bond Financing and Corporate R\&D Input. Bond financing can reduce the cost of debt financing and save interest expenses, leaving enterprises more fund for innovation. Specifically, bond financing lowers financing cost in the following two paths. First, financial intermediaries need to maintain operation and normal profitmaking. The resulting additional cost must be covered by indirect financing price. After bank loans are replaced with bond financing, this additional cost can be saved. Second, bond financing spreads investment risk across multiple investors.
Through largescale bond financing, enterprises could effectively reduce their debt cost.

In addition, bond financing can optimize the financing conditions of bank loans. On the one hand, existent banks are motivated by their debt rights to supervise enterprises. In this way, the banks can get private information about the enterprises. The information asymmetry impedes external banks to acquire similar information at a low cost. As a result, the existent banks can manipulate their information advantage to get monopoly return [14]. The issuance of corporate bonds will disclose a large amount of credit information to the market and reduce the information asymmetry between external banks and enterprises, thereby lowering the information monopoly rent contained in the loan cost [15].

On the other hand, bond issuance opens new debt financing channels for enterprises. With the improvement of the bond market, enterprises obtain more bargaining power, which weakens the monopoly of the banking system in the debt financing market. Furthermore, the monopoly rent contained in the loan cost will be lowered [16]. The saving of interest expenses provides more internal funds to guarantee corporate innovation. Therefore, bond financing will reduce financing cost and in turn ease the financial burden of enterprises, giving more economic supports to their innovation activities.

Furthermore, bond financing extends the overall debt period, prevents the mismatch between short-term loans and long-term investment, and thus promotes corporate $\mathrm{R} \& \mathrm{D}$ input. Innovation investment generally has a longer cycle and a higher adjustment cost than general investment [17]. In the long investment period, even a short interruption of investment could lead to the failure of the innovation project.

To prevent project failure, enterprises must raise sufficient and stable long-term funds beforehand, providing enough support to innovation activities. If the corporate debt funds are mainly supported by bank loans with a short repayment period, rational managers will expect that once the loans expire, the innovation project will be suspended and even terminated, owing to the lack of credit support from the banks. The short debt period threatens the continuity of corporate investment in investment. To cope with the interruption risk of innovation activities, rational managers will cut down innovation projects in advance.

Due to the long repayment period of bond financing, enterprises can utilize much more funds in the medium and long term and ensure the continuity and stability of innovation activities. By extending the debt period, bond financing improves the match between innovation investment cycle and debt financing period and guarantees the smooth implementation of corporate innovation activities.

2.2. R\&D Input and Corporate TFP. In the new classical economic growth model, TFP is manifested as the contribution to economic growth. According to the history of developed countries, the technical progress is directly driven by the accumulation of the knowledge capital generated 
from $R \& D$ input. $R \& D$ input could enhance corporate TFP along two paths:

First, R\&D input can enlarge the knowledge stock of enterprises, including the legally protected patented techniques and nonpatented techniques. Under the action of a series of intermediary factors, the knowledge stock will be converted into productivity and eventually increase corporate TFP [18].

Second, $\mathrm{R} \& \mathrm{D}$ input can change the input proportion of internal elements of enterprises. For example, successful R\&D input definitely drives technical progress: enterprise will purchase more machines and equipment. However, the labor will not shrink in the short term, due to policy factors such as the Labor Law. Overall, the investment scale of enterprises will expand. If the economics of scale is realized, the corporate TFP will surely increase $[19,20]$.

In summary, bond financing could increase corporate $R \& D$ input by reducing financing cost and extending financing period, thereby improve corporate TFP. Therefore, this paper proposes two hypotheses:

$H 1$ : corporate bond financing helps to improve TFP

$H 2$ : corporate bond financing improves TFP by boosting $\mathrm{R} \& \mathrm{D}$ input

\section{Samples and Data}

\subsection{Sample Selection and Data Sources}

3.1.1. China Stock Market \& Accounting Research (CSMAR) Database. Special treatment (ST) and delisting risk ( $\left.{ }^{*} \mathrm{ST}\right)$ : this paper mainly targets the A-share listed enterprises in 2007-2019 and collects the original data from China Stock Market \& Accounting Research (CSMAR) database. Following the standard practice, the initial samples were processed in the following steps: (1) removing the observations in financial industry, (2) removing the observations under special treatment $(\mathrm{ST})$, or facing delisting risk $\left({ }^{*} \mathrm{ST}\right)$, (3) removing the observations facing insolvency, and (4) removing the observations with incomplete data on other control variables. To eliminate the outliers in continuous variables, these variables in the model were winsorized at $1 \%$ and $99 \%$. The processed data contain 19,317 year-enterprise observations.

3.2. Empirical Model and Variable Setting. This paper mainly tests the influence of bond financing on corporate TFP by

$$
\mathrm{TFP}_{i t}=c+\beta_{1} \text { bond }_{i t}+\sum_{j} \beta_{j} \operatorname{control}_{i t}+\mu_{i}+u_{t}+\varepsilon_{i t},
$$

where $\mathrm{TFP}_{i t}$ is corporate TFP, bond ${ }_{i t}$ is corporate bond financing, $\beta_{j}$ is the parameter to be estimated, $\mu_{i}$ is the individual fixed effect, $u_{t}$ is the time fixed effect, and $\varepsilon_{i t}$ is the residual term. To control the influence of time, region, and industry on TFP, as well as heterogeneity between companies, in all regressions, the time fixed effects, individual fixed effects, industry fixed effects, and province fixed effects were controlled, and the standard error was clustered and adjusted on the individual level. The main variables are defined as follows.

3.2.1. Explained Variable: Corporate TFP. Corporate TFP was estimated by the Olley-Pakes (OP) method [21] and the generalized method of moments (GMM) [22]. The GMM results were adopted for robustness test.

\subsubsection{Core Explanatory Variable: Corporate Bond Financing.} This variable was measured by two methods: the dummy variable bond_d of bond financing (if the enterprise has a balance of bonds payable at the end of year $t$, bond $d=1$; otherwise, bond_ $d=0$ ) and the continuous variable of bond financing scale bond_ $p=$ balance of bonds payable/total assets.

3.2.3. Control Variables. Referring to Zhang and Zhang [23], the following corporate eigenvariables were configured: corporate age, corporate scale, corporate ownership, assetliability ratio (ALR), return on equity (ROE), factor intensity, and R\&D fee. The main variables are defined and described in Table 1.

\section{Empirical Results}

4.1. Main Results. Table 2 lists the regression results of model (1). In column (1), the regression coefficient of bond financing dummy variable bond_ $d$ was significantly positive (0.054), i.e., companies with bond financing surpass those without bond financing by 0.054 unit in terms of TFP. In column (2), the regression coefficient of bond financing scale bond_ $p$ was significantly positive (0.003), suggesting that the TFP increases 0.003 unit for each $1 \%$ growth of corporate bond financing. This proves that the growing amount of corporate bond financing can significantly enhance TFP.

The result agrees with H1, i.e., bond financing can effectively increase corporate TFP. A possible reason is that bond financing reduces debt financing cost and extends debt period; the enterprises are thus encouraged to carry out R\&D activities, which contribute to TFP.

According to the regression results on control variables, the coefficients of corporate age, corporate ownership, ALR, ROE, and R\&D fee were significantly positive, while the coefficient of factor intensity was significantly negative. Therefore, state-owned enterprises have a higher TFP than other enterprises. Corporate TFP is positively correlated with corporate age, ALR, ROE, and R\&D fee and negatively correlated with factor intensity. The coefficient of corporate scale was negative but insignificant, suggesting that the corporate scale does not significantly influence corporate TFP. The coefficients of control variables are as expected and consistent with the conclusions of the previous studies.

4.2. Robustness Test. To further test the reliability of the core conclusion, the explained variable was replaced with the TFP derived by GMM for robustness test. The test results are shown in Table 3. Both bond_d and bond_p had significantly 
TABLE 1: Variable definition and description.

\begin{tabular}{lcccc}
\hline Name & Definition & Sample size & Mean & Standard deviation \\
\hline TFP_OP & Referring to Lu Xiaodong and Lian Yujun [22] & 19,317 & 6.344 & 1.003 \\
TFP_GMM & Referring to Deng Xiang et al. [21] & 19,317 & 2.654 & 1.357 \\
bond_d & Presence/absence of balance of bonds payable & 19,317 & 0.158 & 0.365 \\
bond_p & Log of balance of bonds payable & 19,317 & 3.286 & 7.593 \\
Corporate age & Log of the sum of corporate age and 1 & 19,317 & 2.690 & 0.436 \\
Corporate scale & Log of number of employees & 19,317 & 7.666 & 1.215 \\
Corporate ownership & 1 for state-owned enterprise; 0 for other enterprises & 19,317 & 0.106 & 0.308 \\
ALR & Total liabilities divided by total assets & 19,317 & 0.387 & 0.199 \\
ROE & Net profit divided by net assets & 19,317 & 0.0634 & 0.119 \\
Factor intensity & Net fixed assets divided by number of employees & 19,317 & 12.42 & 1.081 \\
R\&D fee & Log of the sum of R\&D fee and 1 & 19,317 & 17.70 & 1.531 \\
\hline
\end{tabular}

TABLE 2: Regression results on bond financing and corporate TFP.

\begin{tabular}{lcc}
\hline Variables & TFP_OP & $(1)$ \\
\hline bond_d & $0.054^{* * *}(3.10)$ & TFP_OP \\
bond_p & & $0.003^{* * *}(3.21)$ \\
Corporate age & $0.130^{* *}(2.45)$ & $0.130^{* *}(2.45)$ \\
Corporate scale & $-0.039(-1.34)$ & $-0.039(-1.35)$ \\
Corporate ownership & $0.061^{* * *}(3.20)$ & $0.062^{* * *}(3.21)$ \\
ALR & $0.724^{* * *}(8.52)$ & $0.723^{* * *}(8.52)$ \\
ROE & $0.626^{* * *}(8.76)$ & $0.626^{* * *}(8.76)$ \\
Factor intensity & $-0.047^{* *}(-2.51)$ & $-0.047^{* *}(-2.51)$ \\
R\&D fee & $0.127^{* * *}(8.35)$ & $0.127^{* * *}(8.35)$ \\
Individual, industry, province, and time fixed effects & Yes & Yes \\
Cons $N$ & $4.298^{* * *}(11.64)$ & $19.300^{* * *}(11.65)$ \\
Adj. $R$-sq & 19,317 & 19,317 \\
\hline
\end{tabular}

Note. ${ }^{* * *},{ }^{* *}$, and ${ }^{*}$ represent significance on $1 \%, 5 \%$, and $10 \%$, respectively; the bracketed values are $t$ values after the standard error of clustering robustness has been adjusted.

TABLE 3: Regression results of robustness test.

\begin{tabular}{|c|c|c|}
\hline Variables & $\begin{array}{c}\text { TFP_GMM } \\
\text { (1) }\end{array}$ & $\begin{array}{c}\text { TFP_GMM } \\
(2)\end{array}$ \\
\hline bond_d & $0.037^{*}(1.66)$ & \\
\hline bond_p & & $0.002^{*}(1.75)$ \\
\hline Corporate age & $0.040(0.61)$ & $0.040(0.61)$ \\
\hline Corporate scale & $-0.352^{* * *}(-11.03)$ & $-0.353^{* * *}(-11.05)$ \\
\hline Corporate ownership & $0.045^{* *}(2.00)$ & $0.046^{* *}(2.01)$ \\
\hline ALR & $0.732^{* * *}(6.74)$ & $0.731^{* * *}(6.74)$ \\
\hline ROE & $0.678^{* * *}(8.71)$ & $0.678^{* * *}(8.71)$ \\
\hline Factor intensity & $-0.516^{* * *}(-24.96)$ & $-0.516^{* * *}(-24.96)$ \\
\hline $\mathrm{R} \& \mathrm{D}$ fee & $0.105^{* * *}(7.46)$ & $0.105^{* * *}(7.46)$ \\
\hline Individual, industry, province, and time fixed effects & Yes & Yes \\
\hline _Cons & $9.452^{* * *}(22.95)$ & $9.454^{* * *}(22.96)$ \\
\hline $\bar{N}$ & 19,317 & 19,317 \\
\hline Adj. $R$-sq & 0.2242 & 0.2242 \\
\hline
\end{tabular}

positive coefficients. Therefore, the conclusion that corporate bond financing can promote TFP is robust.

4.3. Mechanism Analysis. To test whether corporate bond financing promotes TFP by increasing R\&D input, the following mediating effect model was established:

$$
\mathrm{TFP}_{i t}=c+\beta_{1} \text { bond }_{i t}+\beta_{2} \text { innov }+\sum_{j} \beta_{j} \operatorname{control}_{i t}+\mu_{i}+u_{t}+\varepsilon_{i t},
$$

$\operatorname{innov}_{i t}=c+\alpha_{1}$ bond $_{i t}+\sum_{j} \alpha_{j} \operatorname{control}_{i t}+\mu_{i}+u_{t}+\varepsilon_{i t}$, 
TABLE 4: Action mechanism of bond financing on corporate TFP.

\begin{tabular}{|c|c|c|c|c|}
\hline Variables & $\begin{array}{c}\mathrm{R} \& \mathrm{D} \text { fee } \\
\text { (1) }\end{array}$ & $\begin{array}{c}\mathrm{R} \& \mathrm{D} \text { fee } \\
\text { (2) }\end{array}$ & $\begin{array}{c}\text { TFP_OP } \\
\text { (3) }\end{array}$ & $\begin{array}{c}\text { TFP_OP } \\
(4)\end{array}$ \\
\hline bond_d & $0.075^{* * *}(2.93)$ & & $0.054^{* * *}(3.10)$ & \\
\hline bond_p & & $0.004^{* * *}(2.93)$ & & $0.003^{* * *}(3.21)$ \\
\hline $\mathrm{R} \& \mathrm{D}$ fee & & & $0.130^{* *}(2.45)$ & $0.130^{* *}(2.45)$ \\
\hline Corporate age & $-0.171^{* *}(-2.11)$ & $-0.171^{* *}(-2.11)$ & $-0.039(-1.34)$ & $-0.039(-1.35)$ \\
\hline Corporate scale & $0.701^{* * *}(20.34)$ & $0.700^{* * *}(20.32)$ & $0.061^{* * *}(3.20)$ & $0.062^{* * *}(3.21)$ \\
\hline Corporate ownership & $0.051(1.40)$ & $0.052(1.40)$ & $0.724^{* * *}(8.52)$ & $0.723^{* * *}(8.52)$ \\
\hline ALR & $-0.121(-1.25)$ & $-0.122(-1.26)$ & $0.626^{* * *}(8.76)$ & $0.626^{* * *}(8.76)$ \\
\hline ROE & $0.306^{* * *}(4.43)$ & $0.306^{* * *}(4.43)$ & $-0.047^{* *}(-2.51)$ & $-0.047^{* *}(-2.51)$ \\
\hline Factor intensity & $0.130^{* * *}(5.68)$ & $0.130^{* * *}(5.67)$ & $0.127^{* * *}(8.35)$ & $0.127^{* * *}(8.35)$ \\
\hline Individual, industry, province, and time fixed effects & Yes & Yes & Yes & Yes \\
\hline _Cons & $11.188^{* * *}(23.83)$ & $11.190^{* * *}(23.84)$ & $4.298^{* * *}(11.64)$ & $4.300^{* * *}(11.65)$ \\
\hline $\bar{N}$ & 19,317 & 19,317 & 19,317 & 19,317 \\
\hline Adj. $R$-sq & 0.1528 & 0.1528 & 0.1220 & 0.1220 \\
\hline
\end{tabular}

where innov $_{i t}$ is the mediator variable of $R \& D$ input. To control the other factors affecting corporate $\mathrm{R} \& \mathrm{D}$ input, this paper includes control variables of corporate features to formula (3): corporate age, corporate scale, corporate ownership, ALR, ROE, and factor intensity. The regression results are shown in Table 4. The regression coefficient of bond financing dummy variable bond_ $d$ in column (1) and that of bond financing scale bond_ $p$ were significantly positive (0.075 and 0.004), suggesting that companies with bond financing invested $7.5 \%$ higher R\&D fee than those without bonding financing; each $1 \%$ of increase in corporate bond financing brought a $0.4 \%$ growth of corporate R\&D fee. This means companies with bond financing invest more in $\mathrm{R} \& \mathrm{D}$; the greater the bond financing amount, the higher the R\&D investment. The coefficients of the $R \& D$ fee in columns (3) and (4) were both significantly positive (0.130), indicating that each $1 \%$ of increase in $\mathrm{R} \& \mathrm{D}$ investment pushes up corporate TFP by 0.130 unit. Hence, corporate TFP can be significantly enhanced by increasing R\&D input.

Therefore, corporate $\mathrm{R} \& \mathrm{D}$ significantly mediates the promoting effect bond financing on TFP, which proves $H 2$.

\section{Conclusion}

Under the background of financial repression, Chinese enterprises are not enthusiastic about $\mathrm{R} \& \mathrm{D}$ input, which impedes the promotion of TFP. To encourage enterprises to carry out R\&D and thus increase TFP, this paper focuses on the influence of corporate bond financing on TFP and provides theoretical bases for improving TFP from the angle of corporate bond financing. Firstly, the action mechanism of bond financing on corporate TFP was analyzed. Then, listed enterprises were taken as samples to empirically test the influence of bond financing on corporate TFP, as well as the mechanism of that influence. Two main conclusions were drawn. First, corporate bond financing helps to promote TFP. Second, corporate bond financing lowers financing cost, extends financing period, and encourages enterprises to step up R\&D input, thereby promoting TFP.

Based on the conclusions, two policy suggestions were put forward: (i) Improve the market-based issuance mechanism, and continue to expand the scale of bond issuance.

To improve liquidity and untap market potential, we should continue to advance the market-based reform of the bond issuance transaction system and give full play to the decisive role of the market in resource allocation.

Besides, we should simplify the bond issuance procedure, improve the rules, and relax control. Meanwhile, the pricing of bonds should be more transparent, and all the relevant information should be disclosed.

Finally, we should accelerate the expansion of the bond market, build and improve a graded bond market, and make full use of the supportive role of the bond market in corporate financing.

(ii) Improve the diversity of bonds in the market, and provide convenience to corporate bond financing.

Based on the steady development of traditional products (e.g., corporate bonds), we should improve the design of other constant-return structured products, innovate asset securitization products, and better support corporate financing. By creating favorable conditions for corporate bond financing, it is possible to improve corporate TFP and contribute to the sustained health growth of the economy.

\section{Data Availability}

The data used to support the findings of this study are available from the corresponding author upon request.

\section{Conflicts of Interest}

The authors declare that they have no conflicts of interest.

\section{Acknowledgments}

This work was supported by Yulin City Federation of Social Sciences Project "Research on Financial Support for the Development of Agricultural Industrialization in Yulin City" (Grant no. YLSKGH2020-45). 


\section{References}

[1] P. M. Romer, "Increasing returns and long-run growth," Journal of Political Economy, vol. 94, no. 5, pp. 1002-1037, 1986.

[2] J. Zhang and Y. Jin, "Analysis on relationship of deepening financial intermediation and economic growth in China," Economic Research Journal, vol. 11, pp. 34-45, 2005.

[3] F. Arizala, E. Cavallo, and A. Galindo, "Financial development and TFP growth: cross-country and industry-level evidence," Applied Financial Economics, vol. 23, no. 6, pp. 433-448, 2013.

[4] J. Han and Y. Shen, "Financial development and total factor productivity growth: evidence from China," Emerging Markets Finance and Trade, vol. 51, no. s1, pp. S261-S274, 2015.

[5] H. Chen, "Development of financial intermediation and economic growth: the Chinese experience," China Economic Review, vol. 17, no. 4, pp. 347-362, 2006.

[6] S. Y. Xu and Z. Q. Hong, "Financial development and negative efficiency spillovers under credit discrimination," Journal of Financial Research, vol. 2016, no. 5, pp. 51-64, 2016.

[7] G. Chen, S. Li, and Y. Liu, "Bank credit, stock market financing and China's total factor productivity dynamics," Economic Review, vol. 66, no. 6, pp. 47-56, 2009.

[8] R. Gatti and I. Love, "Does access to credit improve productivity? Evidence from Bulgaria," The Economics of Transition, vol. 16, no. 3, pp. 445-465, 2008.

[9] K. Krishnan, D. K. Nandy, and M. Puri, "Does financing spur small business productivity? Evidence from a natural experiment," Review of Financial Studies, vol. 28, no. 6, pp. 1768-1809, 2015.

[10] A. Caggese, Financing Constraints, Radical versus Incremental Innovation, and Aggregate Productivity, no. No. 865, 2015.

[11] P. Ge, C. H. Gan, and S. L. Li, "The Loss of output efficiency caused by financial constraints: data from industrial enterprises in China," Industrial Economics Research, vol. 2017, no. 1, pp. 37-48, 2017.

[12] P.-H. Hsu, X. Tian, and Y. Xu, "Financial development and innovation: cross-country evidence," Journal of Financial Economics, vol. 112, no. 1, pp. 116-135, 2014.

[13] Y. Zhang, Q. Gong, and Z. Rong, "Technological innovation, equity financing, and financial structure transition," Journal of Financial Research, vol. 11, pp. 65-80, 2016.

[14] R. G. Rajan, "Insiders and outsiders: the choice between informed and arm's-length debt," The Journal of Finance, vol. 47, no. 4, pp. 1367-1400, 1992.

[15] G. Hale and J. A. C. Santos, "Do banks price their informational monopoly?" Journal of Financial Economics, vol. 93, no. 2, pp. 185-206, 2009.

[16] G. Q. Dai and L. L. Qian, "Relationship lending, bond financing and cost of firm's loan: a research from the perspective of information and competition mechanism," Journal of Audit \& Economics, vol. 2017, no. 5, pp. 62-73, 2017.

[17] B. H. Hall, "The financing of research and development," Oxford Review of Economic Policy, vol. 18, no. 1, pp. 35-51, 2002.

[18] Z. Griliches, 4. Productivity, R\&D, and Basic Research at the Firm Level in the 1970s, pp. 82-99, University of Chicago Press, Chicago, USA, 2007.

[19] A. Goto and K. Suzuki, "R\&D capital, rate of return on R\&D investment and spillover of R\&D in Japanese manufacturing industries," The Review of Economics and Statistics, vol. 71, no. 4 , pp. 555-564, 1989.
[20] B. H. Hall and J. Mairesse, "Exploring the relationship between R\&D and productivity in French manufacturing firms," Journal of Econometrics, vol. 65, no. 1, pp. 263-293, 1995.

[21] X. Deng, G. F. Zhu, and D. S. Li, "Human capital, trade opening and regional total factor productivity: based on GML index and system GMM method," Inquiry into Economic Issues, vol. 2017, no. 8, pp. 1-8, 2017.

[22] X. D. Lu and Y. J. Lian, "Estimation of total factor productivity of industrial enterprises in China: 1999-2007," China Economic Quarterly, vol. 11, no. 2, pp. 541-558, 2012.

[23] Y. Y. Zhang and D. Y. Zhang, "Can trade credit increase the firms' TFP? a perspective from financial constraints of Chinese firms," Public Finance Research, vol. 2019, no. 2, pp. 116-128, 2019. 